Статья с открытым доступом под лицензией CC BY-NC-ND (https://creativecommons.org/licenses/by-nc-nd/3.0/) Материалы Международной практической интернет-конференции «Актуальные проблемы науки»

Выпуск II, ноябрь 2019

ISBN 978-601-323-144-0

https://doi.org/10.31643/2019.021

Кайруллина Балнур

КазНПУ им. Абая,Казахстан

E-mail: kayrullina94@mail.ru

\title{
Проблема профессиональной адаптации молодых педагогов
}

\begin{abstract}
Абстракт: Значимое внимание к вопросам подготовки начинающего педагога, успешности адаптивного периода начинающих специалистов не случайно. На сегодняшний день именно на молодом специалисте сосредоточены интересы государства и общества. Ведь будущий специалист является не только носителем определенной суммы знаний, но именно ему придется воспитывать будущее поколение патриотов, духовно и физически образованных граждан, осознающих важность общечеловеческих ценностей.

Ключевые слова: адаптация, молодой специалист, виды адаптации, компоненты профессионального развития.
\end{abstract}

\section{Введение}

Проблемам социально-психологической и профессионально педагогической адаптации молодых педагогов рассматривают в тесной взаимосвязи. Вхождение его в профессию происходит одновременно с вхождением в новую социальную среду, в общество. Можно с полным правом рассматривать профессиональную адаптацию и адаптацию социально- психологическую как две стороны единого, целостного процесса, но следует иметь в виду, что эти процессы не тождественны.

В Казахстане различные аспекты проблемы становления личности молодого педагога и успешность профессиональной подготовки будущего учителя находится в прямой зависимости от обучения его пониманию сущности педагогического процесса и умения управлять им.

Последние десятилетия- эта эпоха реформирования образования, школы, личности и педагога, и ребенка, их отношения к жизни и действительности, друг другу, формирование новых педагогических идей, нового типа мышления. Согласно новой парадигме образования современная школа- это открытая система, гуманистически ориентированная, развивающая и развивающаяся.

\section{Обсуждение}

Вступая в педагогическую деятельность, молодой педагог попадает в новую для него социальную и профессиональную среду, а также в новые режимы умственных и физических нагрузок, в новую сферу отношений и взаимодействия. В связи с этим, перед каждым молодым специалистом с первых дней вступления в трудовую деятельность встает ряд взаимообусловленных задач: - найти оптимальные варианты взаимодействия со всеми участниками учебного процесса учащимися, коллегами, администрацией образовательного учреждения, родителями; - умело применять знания и практические навыки, полученные в педагогическом учебном заведении, предварительно оценив уровень использования инновационных методов в учебном процессе и 
целесообразность внедрения нововведений; - оценить собственные способности, требования нового социального окружения, профессиональную деятельность и при необходимости постараться скорректировать свое поведение. Последовательное решение вышеупомянутых задач является необходимым условием для благоприятной последующей социально-профессиональной адаптации педагога, начинающего трудовую жизнь.

В процессе трудовой адаптации молодой педагог проходит следующие стадии:

Стадия ознакомления, на которой работник получает информацию о новой ситуации в целом, о критериях оценки различных действий, о нормах поведения в коллективе. Стадия приспособления или формального вступления - на этом этапе работник переориентируется, признавая главные элементы новой системы ценностей, но пока продолжает сохранять многие свои установки. Стадия ассимиляции, когда осуществляется полное приспособление работника к среде, идентификация с новой группой. Идентификация, когда личные цели работника отождествляются с целями трудовой организации. Прохождение всех этих стадий будет быстрым и продуктивным, если будут приложены усилия не только администрации учреждения, но и в первую очередь молодого специалиста. Молодому педагогу в процессе профессиональной адаптации приходится осваивать одновременно несколько профессиональных ролей: учителя, воспитателя, классного руководителя, подчиненного, коллеги, члена методического объединения учителей. При этом какая бы задача ни стояла перед педагогом необходимо справиться с ней, демонстрируя все свои умения и навыки, которые зачастую оказываются не на высоком уровне. В связи с этим нам хотелось бы выделить некоторые задачи по оказанию помощи начинающим педагогам в процессе профессиональной адаптации: Изучение реальных затруднений и формулирование актуальных потребностей. Информационная и консультативная поддержка начинающих педагогов в выборе программ повышения квалификации, выстраивание индивидуального образовательного маршрута. Формирование информационного банка образовательных услуг для молодых специалистов округа. Организация курсов повышения квалификации. Участие в творческих лабораториях, тренингах. Консультирование молодых специалистов. Участие в научно-практических конференциях. Вовлечение в экспериментальную работу. Обеспечение методической литературой, материалами перспективного планирования, дидактическими материалами, знакомство с методическим кабинетом. Активное включение в мероприятия, как в учреждении, так и за его пределами. Своевременная положительная оценка труда педагога. Заметив педагогические успехи новичка, необходимо непременно отметить это вслух. Похвала стимулирует, вселяет уверенность, повышает интерес к делу, мотивирует.

\section{Вывод}

Таким образом, профессиональное становление молодого педагога происходит непрерывно, шаг за шагом. В результате, грамотное, качественное управление процессом профессиональной адаптации и становления начинающих педагогов, помогает как профессиональному росту самих молодых специалистов, так и способствует развитию общеобразовательного учреждения и конечно же сказывается на результатах учеников, ради успехов которых учитель усердно трудится. Безусловно, ни из одного педагогического вуза или колледжа не выпускается стопроцентно сформированный, высококвалифицированный специалист. Именно в образовательном учреждении происходит процесс становления педагога как профессионала. Поэтому администрации учебного заведения в первую очередь стоит позаботиться о новом сотруднике, создать именно такие организационно-педагогические условия, в которых переход от теории к практике был бы успешным. Благоприятный социально-психологический климат, наличие педагога-наставника, определение и разработка методической деятельности, основанные на личностно-ориентированном подходе и многое другое позволит помочь педагогу проявить себя и адаптироваться на любом рабочем месте.

\section{Благодарность}

Работа выполнена при поддержке Казахстанского Национального Педагогического Университета имени Абая г. Алматы, Республика Казахстан / Министерства образования и науки Республики Казахстан. Автор выражает благодарность профессору Абдуллаевой Г.О. 


\author{
Kairullina Balnur \\ Abay Kazakh National Pedagogical University \\ E-mail: kayrullina94@mail.ru
}

\title{
The problem of professional adaptation of young teachers
}

\begin{abstract}
Significant attention to the issues of training a novice teacher, the success of the adaptive period of novice specialists is not accidental. Today it is the young specialist who focuses the interest of the state and society. After all, the future specialist is not only the bearer of a certain amount of knowledge, but he will have to educate the future generation of patriots, spiritually and physically educated citizen who are aware of the importance of universal
\end{abstract} values.

Keywords: adaptation, young specialist, types of adaptation, professional development components.

Ссылка на данную статью: Кайруллина Б. (2019) Проблема профессиональной адаптации молодых педагогов. Материалы Международной практической интернетконференции «Актуальные проблемы науки» / Materials of International Practical Internet Conference "Challenges of Science". ISBN 978-601-323-144-0. Выпуск II, 2019. Стр.: 107109. https://doi.org/10.31643/2019.021

\section{Список литературных источников}

[1] Тхагопсоев Х. Г. Учитель и культура: проблемы подготовки педагогических кадровю // Педагогика, 1998, №1, C. 66-72.

[2] Асеев В.Г. Теоретические аспекты проблемы адаптации // В кн. Адаптация учащихся и молодежи к трудовой и общественной деятельности. Иркутск, 1986, С.3-17.

[3] Хмель Н.Д. Педагогический процесс в общеобразовательной школе, Алматы: Мектеп, 1984, 134 с..

[4] Немченко В.С. и др. Профессиональная адаптация молодежи, Моск ва: МГУ, 1989,128c.

[5] Заморская Т.В. Психолого-педагогические особенности совершенствования профессиональной компетентности педагогов-психологов в условиях ИПК: Учебно-метод. пособие-Тамбов: ТОИПКРО,2003.-С51.

[6] Скульский Р.П. Учиться быть учителем. Москва: Педагогика , 1986, $143 \mathrm{c}$.

[7] Лушников И.Д. Профессиональная адаптация выпускников пединститутов. Москва: Прометей, 1991, 185c.

[8] Шептенко П.А. Профессиональная адаптация молодого учителя сельской школы в процессе стажировки. Автореф. канд. пед. наук: 14.08. 84. М.: МГПИ, 1983. 20c.

[9] Мороз А.Г, Адаптация молодого учителя к условиям учебно - воспитательного процесса школы. Киев, 1985, 51с.

[10] Кузьмина Н.В. Формирование педагогических способностей. Ленинград: ЛГУ, 1961, 98с.

[11] Кузьмина Н.В. Методы исследования педагогической деятельности. Ленинград: ЛГУ, 1970, 104с.

[12] Хмель Н.Д. Особенности формирования педагогической культуры, Алматы, 1996, 35c. 